\title{
Distribution of Group-Specific Component/Vitamin D-Binding Protein Alleles in Southwestern Japan and Geographical Clines of Allele Frequencies in Japanese Populations
}

\author{
Kazutoshi $\mathrm{Ago}^{1}$, Isao Yuasa ${ }^{2}$, and Osao Tsuganezawa ${ }^{1}$ \\ 1 Department of Legal Medicine, Faculty of Medicine, Kagoshima University, \\ 8-35-1 Sakuragaoka, Kagoshima 890-8520 \\ 2 Department of Legal Medicine, Tottori University School of Medicine, \\ 86 Nishi-machi, Yonago 680-8503
}

(Accepted December 1, 1998)

\begin{abstract}
To scrutinize the geographical clines of allele frequencies of the group-specific component/vitamin-D binding protein (GC) system in Japan, the GC types in nine populations of southwestern Japan including Okinawa were determined. The frequencies of the common alleles in the island populations, especially, Yakushima and Miyako were found to be scattered more extensively than those in the populations of the mainland Japan. GC*1A2 was polymorphic in all populations except in the southwesternmost islands, Miyako and Ishigaki. The geographical clines of $\mathrm{GC}^{*} 1 \mathrm{~F}, \mathrm{GC}^{*} 1 \mathrm{~S}$ and $\mathrm{GC}^{*} 2$ frequencies are discussed in connection with the migration of the Yayoi era.
\end{abstract}

Keywords: Genetic polymorphism, Geographical cline, Group-specific component, Japanese population, vitamin D-binding protein

\section{Introduction}

Group-specific component (GC), a plasma protein, is currently called vitamin D-binding protein (DBP) after its function (Daiger and others, 1975). However, GC/DBP not only act as a carrier of vitamin D but also has some functions (Constans, 1992). The genetic polymorphism of the human GC/DBP system was first shown to be controlled by $\mathrm{GC}^{*} 1$ and $\mathrm{GC}^{*} 2$ by Hirschfeld (1959) using immunoelectrophoresis. Since Constans and Viau (1977), using isoelectric focusing (IEF), divided $\mathrm{GC}^{*} 1$ into $\mathrm{GC}^{*} 1 \mathrm{~F}$ and $\mathrm{GC}^{*} 1 \mathrm{~S}$, more than 120 variant alleles have been observed at the GC locus on chromosome 4 (Cleve and Constans, 1988). The population distribution of three common alleles, GC*1F, GC*1S and $\mathrm{GC}^{*} 2$ and some variant alleles have been studied to elucidate human microevolutions (Constans and others, 1985).

Geographical clines of allele frequencies are useful to consider historical events, migration and natural selection. Some geographical clines associated with migration have been recognized in Japanese populations (Ishimoto and Kuwata, 1974; Fujita and others, 
1978; Ueda and others, 1979; Yuasa and others, 1983a, 1983b; Omoto, 1986; Nakanaga and others, 1991). Recently, we examined the clines arising from the differences in TF allele frequencies between the aboriginal people of the Jomon era and the immigrants from north Asia in the Yayoi era using data from the Nansei Islands (Ago and others, 1998). The Nansei Islands which comprise the Satsunan Islands and the Ryukyu Islands consist of many islands scattered like a longbow between mainland Kagoshima Prefecture in Japan and Taiwan (Ago and others, 1998). Jomon characteristics remain more noticeable in the peripheral populations of the Nansei Islands than in the mainlanders, since the Yayoi immigrants came mainly to the western part of the mainland Japan from or through the Korean Peninsula. Thus the Nansei Islands are important in tracing the origins of the Japanese people (Hanihara, 1991). To scrutinize the geographical clines in Japan, in this paper, we investigate the distribution of GC allele frequencies in the populations of the Nansei Islands.

\section{Materials and Methods}

Serum samples were obtained from blood donors living in nine regions as shown in Table 1. One region is mainland Kagoshima Prefecture, and the remaining eight are islands: Tanegashima, Yakushima, Amami-oshima, Tokunoshima and Okinoerabu in the Satsunan Islands, and Okinawa, Miyako and Ishigaki in the Ryukyu Islands.

GC phenotyping was carried out by IEF on acrylamide gel containing Pharmalyte pH 4.5-5.4 (Pharmacia, Uppsala, Sweden) followed by immunoprinting or immunoblotting with monospecific anti-GC serum (Dako, Glostrup, Denmark).

The geographical clines for the frequencies of common GC alleles in Japanese populations were examined as described previously (Ago and others, 1998). In brief, simple linear regression between allele frequencies and distances was statistically tested at the 5\% level. The distances were measured along railroads and sea routes from Aomori, Osaka and Yamaguchi to the investigated districts.

Table $1 \mathrm{GC}$ allele frequencies in the populations of the Nansei Islands and mainland Kagoshima Prefecture

\begin{tabular}{|c|c|c|c|c|c|c|c|c|c|c|c|}
\hline \multirow{2}{*}{ Populations } & \multirow{2}{*}{$\mathrm{n}$} & \multicolumn{10}{|c|}{ Frequencies } \\
\hline & & $\mathrm{GC}^{*} 1 \mathrm{~F}$ & $\mathrm{GC}^{*} 1 \mathrm{~S}$ & $\mathrm{GC}^{*} 2$ & $\mathrm{GC}^{*} 1 \mathrm{~A} 2$ & $\mathrm{GC}^{*} 1 \mathrm{~A} 3$ & $\mathrm{GC}^{*} 1 \mathrm{~A} 8$ & $\mathrm{GC}^{*} 1 \mathrm{~A} 9$ & $\mathrm{GC}^{*} 1 \mathrm{C} 2$ & $\mathrm{GC}^{*} 1 \mathrm{C} 4$ & $\mathrm{GC}^{*} 1 \mathrm{C} 35$ \\
\hline Mainland & 349 & 0.4628 & 0.2335 & 0.2851 & 0.0115 & 0.0029 & - & 0.0043 & - & - & - \\
\hline Tanegashima & 320 & 0.4859 & 0.1891 & 0.3047 & 0.0172 & 0.0016 & - & 0.0016 & - & - & - \\
\hline Yakushima & 365 & 0.4411 & 0.2753 & 0.2671 & 0.0110 & 0.0014 & - & 0.0014 & 0.0014 & 0.0014 & - \\
\hline Amami-oshima & 370 & 0.4297 & 0.1959 & 0.3459 & 0.0176 & - & 0.0014 & 0.0068 & - & 0.0027 & - \\
\hline Tokunoshima & 280 & 0.4732 & 0.1893 & 0.3179 & 0.0125 & 0.0018 & - & 0.0036 & - & 0.0018 & - \\
\hline Okinoerabu & 371 & 0.4636 & 0.2426 & 0.2695 & 0.0175 & 0.0013 & - & 0.0027 & - & 0.0027 & - \\
\hline Okinawa & 362 & 0.4461 & 0.2099 & 0.3149 & 0.0193 & 0.0014 & 0.0014 & 0.0055 & - & - & 0.0014 \\
\hline Miyako & 350 & 0.5514 & 0.1729 & 0.2643 & 0.0086 & - & - & - & 0.0014 & 0.0014 & - \\
\hline Ishigaki & 332 & 0.4864 & 0.2018 & 0.3012 & 0.0075 & - & - & 0.0030 & - & - & - \\
\hline
\end{tabular}




\section{Results}

Six common and 16 variant phenotypes were observed. A homozygote of GC*1A2 was observed in Tanegashima and Okinoerabu, and a rare heterozygous phenotype GC1A31A9, in mainland Kagoshima. In all the populations except Okinoerabu the observed numbers were in agreement with expectations assuming Hardy-Weinberg equilibrium ( $p>0.05$ ). As shown in Table 1, the frequencies of common alleles were: 0.4297-0.5514 for $\mathrm{GC}^{*} 1 \mathrm{~F}, 0.1729-0.2753$ for $\mathrm{GC}^{*} 1 \mathrm{~S}$ and $0.2643-0.3459$ for $\mathrm{GC}^{*} 2$. The chi-square test using the frequencies of $\mathrm{GC}^{*} 1 \mathrm{~F}, \mathrm{GC}^{*} 1 \mathrm{~S}$ and $\mathrm{GC}^{*} 2$ at the $5 \%$ level showed that Yakushima and Miyako (especially Yakushima) significantly differed from other populations. However, Yakushima was not significantly different from mainland Kagoshima. Of several rare variants observed, $\mathrm{GC}^{*} 1 \mathrm{~A} 2$ was the most common in all populations and polymorphic (>0.01) except in Miyako and Ishigaki.

The geographical clines of GC allele frequencies in Japanese populations were examined using the present and previous data, as shown in Table 2. As described in the analysis of clines in the TF system (Ago and others, 1998), three localities were examined as the origin of the clines. Firstly, as in previous studies (Yuasa and others, 1983a, 1983b; Omoto, 1986) clines were examined by measuring distances from Aomori. The distribution patterns of the allele frequencies are shown in Figure 1. There were statistically significant clines increasing in frequency for $\mathrm{GC}^{* 2}(\mathrm{y}=0.0183 \mathrm{x}+0.2469$, $\mathrm{R}=0.73, \mathrm{~F}=32.8, \mathrm{n}=31, \mathrm{P}<0.001)$ and decreasing for $\mathrm{GC}^{*} 1 \mathrm{~S}(\mathrm{y}=-0.0173 \mathrm{x}+0.2646$, $\mathrm{R}=0.66, \mathrm{~F}=22.4, \mathrm{n}=31, \mathrm{P}<0.001)$ from Aomori to Ishigaki, but not for $\mathrm{GC}^{*} 1 \mathrm{~F}$.

Table 2 Distribution of GC allele frequencies in populations throughout Japan

\begin{tabular}{|c|c|c|c|c|c|c|c|c|}
\hline \multirow{2}{*}{ Populations } & \multirow{2}{*}{$\mathrm{n}$} & \multicolumn{3}{|c|}{ Frequencies } & \multicolumn{3}{|c|}{ Distance $(\mathrm{Km})$ from } & \multirow{2}{*}{ References } \\
\hline & & $\mathrm{GC}^{*} 1 \mathrm{~F}$ & $\mathrm{GC}^{*} 1 \mathrm{~S}$ & $\mathrm{GC}^{*} 2$ & Aomori & Osaka & Yamaguchi & \\
\hline Aomori & 593 & 0.4545 & 0.2470 & 0.2664 & 0 & -1296 & -1779 & Yoshioka and others, 1984 \\
\hline Akita & 732 & 0.4693 & 0.2473 & 0.2582 & 186 & -1128 & -1611 & Shindo and Takahashi, 1983 \\
\hline Iwate & 697 & 0.4699 & 0.2461 & 0.2518 & 204 & -1092 & -1575 & Yoshioka and others, 1984 \\
\hline Iwate & 500 & 0.480 & 0.238 & 0.242 & 204 & -1092 & -1575 & Omoto, 1986 \\
\hline Miyagi & 647 & 0.4359 & 0.2666 & 0.2589 & 387 & -908 & -1392 & Yoshioka and others, 1984 \\
\hline Yamagata & 689 & 0.4347 & 0.2612 & 0.2663 & 450 & -916 & -1400 & Umetsu and others, 1985 \\
\hline Fukushima & 893 & 0.4854 & 0.2402 & 0.2469 & 466 & -829 & -1313 & Abe, 1983 \\
\hline Tokyo & 305 & 0.4656 & 0.2590 & 0.2574 & 739 & -556 & -1040 & Omoto and Miyake, 1978 \\
\hline Tokyo & 531 & 0.487 & 0.241 & 0.246 & 739 & -556 & -1040 & Ishimoto and others, 1979 \\
\hline Tokyo & 526 & 0.4695 & 0.2610 & 0.2438 & 739 & -556 & -1040 & Nakajima and Nakazawa, 1980 \\
\hline Yamanashi & 530 & 0.4642 & 0.2557 & 0.2547 & 873 & -499 & -982 & Kido and others, 1984 \\
\hline Toyama & 1047 & 0.429 & 0.255 & 0.282 & 696 & -327 & -810 & Ohya and others, 1986 \\
\hline Mie & 510 & 0.465 & 0.241 & 0.263 & 1149 & -127 & -610 & Ishimoto and others, 1979 \\
\hline Osaka & 316 & 0.4209 & 0.3006 & 0.2579 & 1296 & 0 & -483 & Matsumoto and others, 1979 \\
\hline Osaka & 342 & 0.456 & 0.258 & 0.254 & 1296 & 0 & -483 & Shibata, 1983 \\
\hline \multicolumn{9}{|l|}{ Hyogo } \\
\hline Awajishima & 218 & 0.4633 & 0.2454 & 0.2546 & 1355 & 60 & -438 & Fukui and others, 1993 \\
\hline
\end{tabular}


Table 2. continued

\begin{tabular}{|c|c|c|c|c|c|c|c|c|}
\hline \multirow{2}{*}{ Populations } & \multirow{2}{*}{$\mathrm{n}$} & \multicolumn{3}{|c|}{ Frequencies } & \multicolumn{3}{|c|}{ Distance $(\mathrm{Km})$ from } & \multirow{2}{*}{ References } \\
\hline & & $\mathrm{GC}^{*} 1 \mathrm{~F}$ & $\mathrm{GC}^{*} 1 \mathrm{~S}$ & $\mathrm{GC}^{*} 2$ & Aomori & Osaka & Yamaguchi & \\
\hline Kochi & 1460 & 0.4527 & 0.2370 & 0.2836 & 1651 & 356 & -486 & Ishizu and others, 1986 \\
\hline \multicolumn{9}{|l|}{ Shimane } \\
\hline Izumo & 600 & 0.4524 & 0.2462 & 0.2780 & 1605 & 378 & -244 & Yuasa and others, 1984 \\
\hline Yamaguchi & 400 & 0.4422 & 0.2450 & 0.2802 & 1779 & 483 & 0 & Yuasa and others, 1984 \\
\hline Nagasaki & 1058 & 0.4409 & 0.2356 & 0.2909 & 2069 & 773 & 316 & Nakasono and others, 1983 \\
\hline \multicolumn{9}{|l|}{ Kagoshima } \\
\hline Mainland & 349 & 0.4628 & 0.2335 & 0.2851 & 2235 & 940 & 482 & Present study \\
\hline Tanegashima & 320 & 0.4859 & 0.1891 & 0.3047 & 2350 & 1055 & 597 & Present study \\
\hline Yakushima & 365 & 0.4411 & 0.2753 & 0.2671 & 2370 & 1075 & 617 & Present study \\
\hline Amami-oshima & 370 & 0.4297 & 0.1959 & 0.3459 & 2618 & 1323 & 865 & Present study \\
\hline Tokunoshima & 280 & 0.4732 & 0.1893 & 0.3179 & 2727 & 1432 & 974 & Present study \\
\hline Okinoerabu & 371 & 0.4636 & 0.2426 & 0.2695 & 2881 & 1486 & 1028 & Present study \\
\hline \multicolumn{9}{|l|}{ Okinawa } \\
\hline Okinawa & 502 & 0.4731 & 0.2092 & 0.3157 & 2968 & 1673 & 1215 & Matsumoto and others, 1980 \\
\hline Okinawa & 397 & 0.4332 & 0.2141 & 0.3212 & 2968 & 1673 & 1215 & Yuasa, 1987 \\
\hline Okinawa & 362 & 0.4461 & 0.2099 & 0.3149 & 2968 & 1673 & 1215 & Present study \\
\hline Miyako & 350 & 0.5514 & 0.1729 & 0.2643 & 3298 & 2003 & 1545 & Present study \\
\hline Ishigaki & 332 & 0.4864 & 0.2018 & 0.3012 & 3409 & 2114 & 1656 & Present study \\
\hline
\end{tabular}

Secondly, the clines were separately examined in two parts, eastern (Aomori - Yamaguchi) and western (Yamaguchi - Ishigaki) Japan. As shown in Figure 2, GC*1F and GC*1S frequencies were distributed in a V shape and in an inverted $\mathrm{V}$ shape, respectively. The slopes of the clines differed in directionality between the eastern and the western groups. The frequencies of $\mathrm{GC}^{*} 2$ were lineally distributed. Significant clines were observed for $\mathrm{GC}^{*} 1 \mathrm{~S}$ frequencies $(\mathrm{y}=-0.0337 \mathrm{x}+0.2469, \mathrm{R}=0.572, \mathrm{~F}=5.35, \mathrm{n}=13, \mathrm{P}=0.041)$ in western Japan and for $\mathrm{GC}^{*} 2$ frequencies $(\mathrm{y}=0.0119 \mathrm{x}+0.2717, \mathrm{R}=0.481, \mathrm{~F}=5.11, \mathrm{n}$ $=19, \mathrm{P}=0.037$ ) in eastern Japan. Thirdly, as shown in Figure 3, the origin was shifted to Osaka. In $\mathrm{GC}^{*} 1 \mathrm{~F}$ and $\mathrm{GC}^{*} 1 \mathrm{~S}$ frequencies, the $\mathrm{V}$ shape and the inverted $\mathrm{V}$ shape observed in Figure 2 became more noticeable. The frequencies of $\mathrm{GC}^{*} 2$ were lineally distributed, but the slopes of the two lines in northern and western Japan were slightly different. Significant clines were observed in the western group, where frequencies of GC $* 1 \mathrm{~F}$ increased $(\mathrm{y}=0.0201 \mathrm{x}+0.4391, \mathrm{R}=0.47, \mathrm{~F}=4.6, \mathrm{n}=18, \mathrm{P}=0.047)$, those of $\mathrm{GC}$ $* 1 \mathrm{~S}$ decreased $(\mathrm{y}=-0.0349 \mathrm{x}+0.2637, \mathrm{R}=0.74, \mathrm{~F}=18.8, \mathrm{n}=18, \mathrm{P}<0.001)$ and those of $\mathrm{GC}^{*} 2$ increased $(\mathrm{y}=0.0221 \mathrm{x}+0.2666, \mathrm{R}=0.57, \mathrm{~F}=7.9, \mathrm{n}=18, \mathrm{P}=0.013)$ from northeast to southwest. 

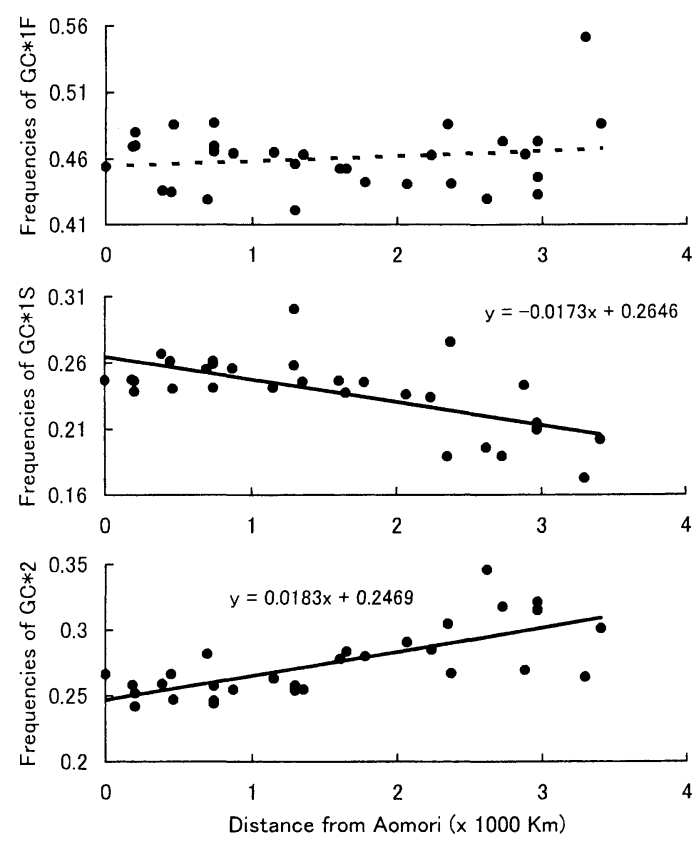

Figure 1 Scatter diagrams and clines of GC allele frequencies in Japanese populations. Dotted line indicates that the cline is not significant at the $5 \%$ level.
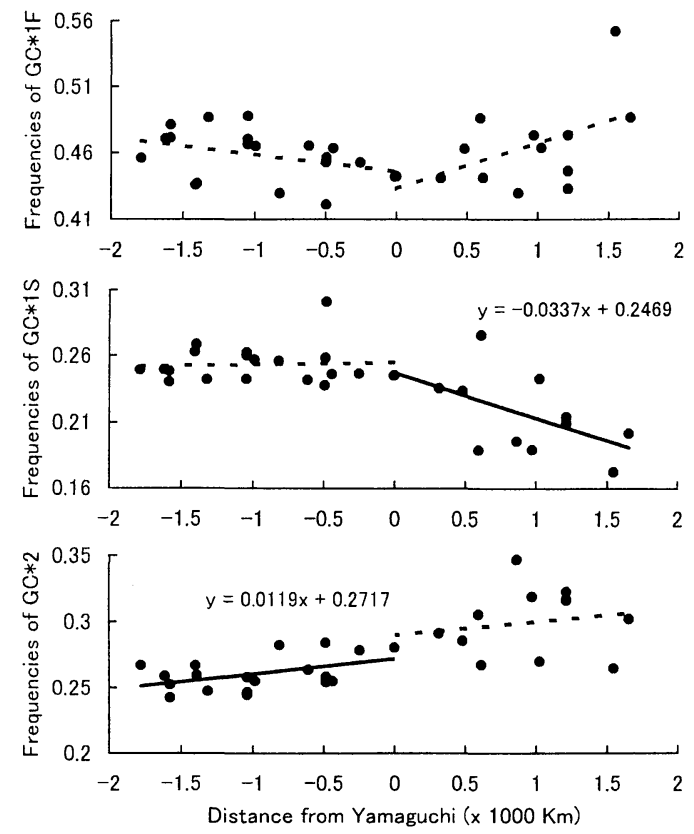

Figure 2 Rearranged scatter diagrams and clines of GC allele frequencies in Japanese populations (1). The dotted line indicates that the cline is not significant at the $5 \%$ level. 

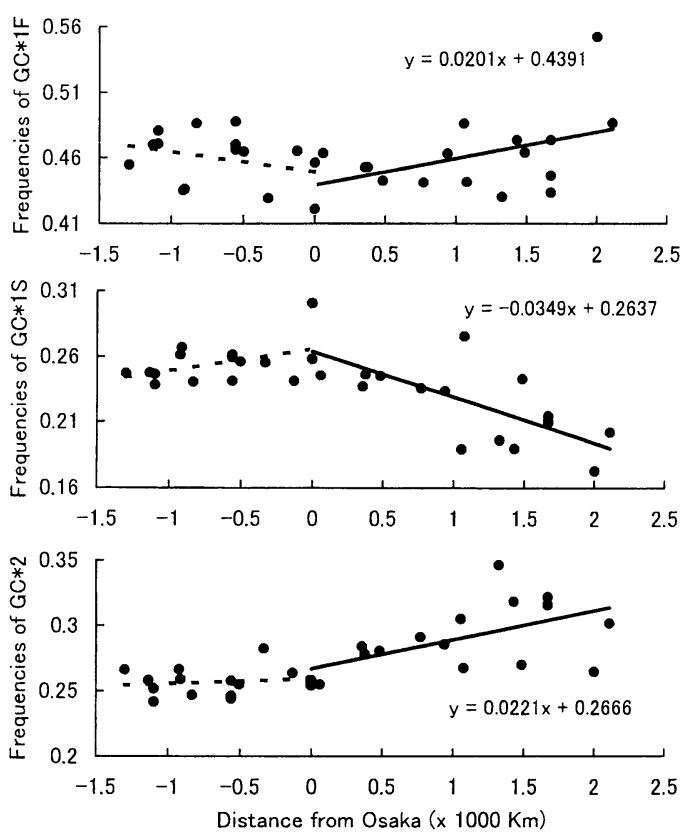

Figure 3 Rearranged scatter diagrams and clines of GC allele frequencies in Japanese populations (2). The dotted line indicates that the cline is not significant at the $5 \%$ level.

\section{Discussion}

The frequencies of common GC alleles in the present populations scattered variably in comparison with those in the mainland Japan, as shown in Table 2 and Figure 1. This may be attributed to the isolation of each island. There was a significant difference in the distribution of allele frequencies between Yakushima and Tanegashima, although they are the closest among the localities investigated in the present study (only about $18 \mathrm{Km}$ from each other). In contrast, no significant difference was observed between Yakushima and mainland Kagoshima. Yakushima was governed by the feudal lords of mainland Kagoshima for about 300 years since 1595 A.D., but Tanegashima kept its independence during this period. These historical differences may have affected the frequencies of the GC alleles. The difference between these two islands is also observed in the alpha 1-antitrypsin system (Ago and Tsuganezawa, 1989). GC*1A2, originally reported as GC *Japan (Omoto and others, 1972), was polymorphic in the populations except in Miyako and Ishigaki, the southwesternmost part (Table 1). It is also a genetic marker for the east Asian populations (Kamboh and Ferrell, 1986; Cleve and Constans, 1988). Its frequency in Japanese populations is much higher than in Chinese populations (Zeng and Omoto, 1987; Xu and others, 1989; Yiping and others, 1992; Umetsu and others, 1992).

Yuasa and others (1983a), using 12 data obtained by immunoelectrophoresis, first reported the geographical cline of GC allele frequency in Japanese populations, where 
$\mathrm{GC}^{*} 2$ frequency increases from north to south between Aomori and Miyazaki. Using 13 data obtained by IEF, Yuasa and others (1983b) confirmed the cline of GC*2 frequencies between Yamagata and Okinawa. Omoto (1986) reported a similar cline between Akita and Nagasaki. The present data supplemented with previous data covered the whole of Japan except Hokkaido, the northernmost part (Table 2). Our first analysis of geographical clines followed the method of previous studies (Yuasa and others, 1983a, 1983b; Omoto, 1986). We found that GC*2 frequency increases from northeast to southwest between Aomori and Ishigaki. In contrast, $\mathrm{GC}^{*} 1 \mathrm{~S}$ frequency decreases in the same area (Figure 1).

Hanihara (1991), on the formation of the Japanese people, described that the modern Japanese population consists of the three main populations, Hondo Japanese inhabiting mainland Japan, Ryukyuans in Okinawa and Ainu in Hokkaido. These populations commonly originate from the Jomonese of the Neolithic Jomon era $(12,000-2,300$ years ago). Later, migration from northeast Asia took place in and after the Aeneolithic Yayoi era (300 B.C. - 300 A.D.). The immigrants mainly came to the northern part of Kyushu and Yamaguchi from or through the Korean Peninsula, and mixed with Hondo Japanese. This population intermixture is still going on. The habitat of the migrants extended from the north part of Kyushu and Yamaguchi to the Kinki district in the early stage (Aoki and Omoto, 1980; Hanihara, 1991; Aoki, 1994). Therefore, we divided the populations into eastern and western groups with borders at Yamaguchi and at Osaka, and reexamined the clines in each group (Figures 2 and 3). The clines for the frequencies of GC*1F and $\mathrm{GC}^{*} 1 \mathrm{~S}$ had different directivity between the eastern and the western groups, and showed $\mathrm{V}$ and inverted $\mathrm{V}$ shapes on scatter diagrams. These features suggest that the clines were formed by the migration of populations with different allele frequencies in the Yayoi era. The clines bordered at Yamaguchi were similar to those bordered at Osaka. This suggests that populations between Yamaguchi and the Kinki district are genetically homogeneous.

The distribution profiles of $\mathrm{GC}^{*} 2$ frequencies were different from those of $\mathrm{GC}^{*} 1 \mathrm{~F}$ and $\mathrm{GC}^{*} 1 \mathrm{~S}$. The clines for $\mathrm{GC}^{*} 2$ in the eastern and western parts have the same directivity increasing from northeast to southwest. $\mathrm{GC}^{*} 2$ frequencies were not remarkably affected by the Yayoi immigrants. The cline of $\mathrm{GC}^{*} 2$ frequencies suggests that the north-south differentiation among the aboriginal people had been formed before the Yayoi migration started, and that the immigrant population had a frequency intermediate between the frequencies of the northern and southern aboriginal people. Thus, the analysis of clines after the division into eastern and western populations is useful to investigate the historical changes of allele frequency distribution.

The data of Ainu populations, $\mathrm{GC}^{*} 1 \mathrm{~F}=0.5214, \mathrm{GC}^{*} 1 \mathrm{~S}=0.2571, \mathrm{GC}^{*} 2=0.2214$ (Omoto and Miyake, 1979) and $\mathrm{GC}^{*} 1 \mathrm{~F}=0.5793, \mathrm{GC}^{*} 1 \mathrm{~S}=0.2030, \mathrm{GC}^{*} 2=0.2085$ (Matsumoto and others, 1980), fit the frequencies expected from the distribution profiles of GC alleles in the other Japanese populations.

On the other hand, Mourant and others (1976) made a world map of GC*2 allele frequencies, and showed that high frequencies of $\mathrm{GC}^{*} 2$ correspond to low levels of 
sunlight with some exceptions. They discussed the results in relation to natural selection and the incidence of rickets, due to vitamin D deficiency. The cline of GC*2 frequencies in Japanese populations, however, is not explicable by natural selection because the frequencies increase from north to south, as indicated by Yuasa and others (1983a). Our previous study on the TF system (Ago and others, 1998) showed that the clines for the frequencies of $\mathrm{TF}^{*} \mathrm{C} 1$ and $\mathrm{TF}^{*} \mathrm{C} 2$ have different directivity between the eastern and the western groups bordered at the western part of Honshu, the main island, like those of GC ${ }^{*} 1 \mathrm{~F}$ and $\mathrm{GC}^{*} 1 \mathrm{~S}$. The findings that similar clines were observed in different systems strongly suggest that the clines were formed by gene flow due to migration, not by natural selection.

\section{Acknowledgments}

We are grateful to M. Ichinose, Y. Nagayoshi and S. Hashiguchi, Kagoshima Red Cross Blood Center, Kagoshima, and to M. Iha, Okinawa Red Cross Blood Center, Naha, Japan, for supplying us with the blood samples. This study was supported in part by a Grant-in-Aid for Scientific Research (09208208 to I. Y.) from the Ministry of Education, Science, Sports and Culture of Japan.

\section{REFERENCES}

Abe S. (1983) Genetic polymorphism of red cell enzymes (AcP, EsD, GPT, 6-PGD) and of serum protein $(\mathrm{Gc})$ in Fukushima Prefecture. The Japanese Journal of Human Genetics, vol. 28, pp. 195-200.

Ago K. and Tsuganezawa O. (1989) Genetic variants of serum proteins and red cell enzymes in Kagoshima prefecture -PI types-. Nippon Houigaku Zasshi, vol. 43 (Supplement), p. 136 (in Japanese).

Ago K., Yuasa I., and Tsuganezawa O. (1998) Transferrin polymorphism in the Nansei Islands: description of a new variant TF Dama and clines of allele frequencies in Japanese populations. Anthropological Science, vol. 106, pp. 209-219.

Aoki K. and Omoto K. (1980) An analysis of the ABO gene frequency cline in Japan: a migration model. Journal of the Anthropological Society of Nippon, vol. 88, pp. 109-122.

Aoki K. (1994) Maximum likelihood fit of a gradual admixture model to clines of gene frequencies in the main islands of Japan. Anthropological Science, vol. 102, pp. 285-294.

Cleve H. and Constans J. (1988) The mutants of the vitamin-D-binding protein: more than 120 variants of the GC/DBP system. Vox Sanguinis, vol. 54, pp. 215-225.

Constans J. and Viau M. (1977) Group-specific component: evidence for two subtypes of the $\mathrm{Gc}^{1}$ gene. Science, vol. 198, pp. 1070-1071.

Constans J., Hazout S., Garruto R.M., Gajdusek D.C., and Spees E.K. (1985) Population distribution of the human vitamin D binding protein: anthropological considerations. American Journal of Physical Anthropology, vol. 68, pp. 107-122. 
Constans J. (1992) Group-specific component is not only a vitamin-D-binding protein. Experimental and Clinical Immunogenetics, vol. 9, pp. 161-175.

Daiger S.P., Schanfield M.S., and Cavalli-Sforza L.L. (1975) Group-specific component (Gc) proteins bind vitamin D and 25-hydroxyvitamin D. Proceedings of the National Academy of Sciences of the United States of America, vol. 72, pp. 2076-2080.

Fujita Y., Tanimura M., and Tanaka K. (1978) The distribution of the ABO blood groups in Japan. The Japanese Journal of Human Genetics, vol. 23, pp. 63-109.

Fukui E., Kario K., Ota Y., and Ikemoto S. (1993) The GC variants among the Japanese population living in the Awaji Island of Hyogo prefecture. Japanese Journal of Electrophoresis, vol. 37, pp. 377-380 (in Japanese).

Hanihara K. (1991) Dual structure model for the population history of the Japanese. Japan Review, vol. 2, pp. 1-33.

Hirschfeld J. (1959) Immune-electrophoretic demonstration of qualitative differences in human sera and their relation to the haptoglobins. Acta Pathologica et Microbiologica Scandinavica, vol. 47, pp. 160-168.

Ishimoto G. and Kuwata M. (1974) Red cell glutamic-pyruvic transaminase polymorphism in Japanese populations. The Japanese Journal of Human Genetics, vol. 18, pp. 373377.

Ishimoto G., Kuwata M., and Nakajima H. (1979) Group-specific component (Gc) polymorphism in Japanese: an analysis by isoelectric focusing on polyacrylamide gels. The Japanese Journal of Human Genetics, vol. 24, pp. 75-83.

Ishizu H., Shogano N., Tsutsumi A., and Yamamoto Y. (1986) Gc subtypes in Kochi prefecture: determination by isoelectric focusing. Acta Criminologiae et Medicinae Legalis Japonica, vol. 52, pp. 221-224.

Kamboh M. and Ferrell R.E. (1986) Ethnic variation in vitamin D-binding protein (GC): a review of isoelectric focusing studies in human populations. Human Genetics, vol. 72, pp. 281-293.

Kido A., Oya M., Komatsu N., and Shibata R. (1984) Distribution of Gc subtypes in Yamanashi Prefecture. Nippon Houigaku Zasshi, vol. 38, pp. 391-396.

Matsumoto H., Toyomasu T., Tamaki Y., Katayama K., and Matsui K. (1979) The distribution of Gc subtypes in Japanese and its application in paternity case. Nippon Houigaku Zasshi, vol. 33, pp. 74-79.

Matsumoto H., Matsui K., Ishida N., Ohkura K., and Teng Y.S. (1980) The distribution of Gc subtypes among the Mongoloid populations. American Journal of Physical Anthropology, vol. 53, pp. 505-508.

Mourant A.E., Tills D., and Domaniewska-Sobczak K. (1976) Sunshine and the geographical distribution of the alleles of the Gc system of plasma poteins. Human Genetics, vol. 33, pp. 307-314.

Nakajima H. and Nakazawa E. (1980) The Gc subtypes in Japanese: further population and family samples. Nippon Houigaku Zasshi, vol. 34, pp. 1-8 (in Japanese).

Nakanaga M., Yasuda T., Tenjo E., Nadano D., Fujiki N., and Kishi K. (1991) Transferrin 
polymorphisms in Japanese populations: north-south cline in the distribution of the TF ${ }^{*} \mathrm{C} 2$ allele. Human Biology, vol. 63, pp. 187-195.

Nakasono I., Iwasaki M., Ogata M., Yoshida C., Yoshitake T., Narita K., Fukae T., and Suyama H. (1983) The distribution of Gc subtypes in the Japanese population of Nagasaki district. Acta Criminologiae et Medicinae Legalis Japonica, vol. 49, pp. 253257.

Ohya I., Komoriya H., and Nakamura I. (1986) The distribution of GC subtypes in the Japanese population of Toyama district. Acta Criminologiae et Medicinae Legalis Japonica, vol. 52, pp. 163-169.

Omoto K., Cleve H., and Misawa S. (1972) A new variant phenotype of the groupspecific component $(\mathrm{Gc})$ found in a Japanese family. The Japanese Journal of Human Genetics, vol. 17, pp. 1-9.

Omoto K. and Miyake K. (1978) The distribution of the group-specific component (Gc) subtypes in Japanese. The Japanese Journal of Human Genetics, vol. 23, pp. 119-125.

Omoto K. and Miyake K. (1979) The distribution of subtypes of serum Gc-globulin in Japanese and the neighbouring populations. The Japanese Journal of Human Genetics, vol. 24 , pp. 224-225.

Omoto K. (1986) The distribution of red cell enzyme and serum protein types in a sample from Iwate, northern Japan, with the description of geographical cline of Gc subtypes. Journal of the Anthropological Society of Nippon, vol. 94, pp. 51-63.

Shibata K. (1983) Haptoglobin, group-specific component, transferrin and $\alpha 1$-antitrypsin subtypes and new variants in Japanese. The Japanese Journal of Human Genetics, vol. 28, pp. 17-27.

Shindo S. and Takahashi K. (1983) Phenotypes of group specific component and $\alpha 1$ antitrypsin in Akita area. The Research and Practice in Forensic Medicine, vol. 26, pp. 7-11 (in Japanese).

Ueda S., Omoto K., Park K.S., and Kudo T. (1979) Polymorphism of red cell glutamicpyruvic transaminase in Japanese: gene frequencies in samples from northern Japan. Human Heredity, vol. 29, pp. 208-212.

Umetsu K., Ikeda N., Kashimura S., and Suzuki T. (1985) The distribution of GC, TF, PI and PGM1 subtypes in Yamagata Prefecture. Nippon Houigaku Zasshi, vol. 39, pp. $11-14$.

Umetsu K., Ding M., Yuasa I., and Suzuki T. (1992) Genetic polymorphism of groupspecific component in a Chinese population. The Research and Practice in Forensic Medicine, vol. 35, pp. 67-69 (in Japanese).

Xu J., Tan Q., and Du R. (1989) Studies of subtypes of group specific component (GC) in six ethnic groups of China. Gene Geography, vol. 3, pp. 27-31.

Yiping H., Qing G., and Meiyun W. (1992) Genetic polymorphisms of alpha-2-HSglycoprotein, group-specific component and orosomucoid in the Han population, Chengdu, China. Human Heredity, vol. 42, pp. 380-383.

Yoshioka N., Shindo S., and Kudo T. (1984) Distribution of group specific component 
subtypes among Japanese. The Research and Practice in Forensic Medicine, vol. 27, pp. 39-45 (in Japanese).

Yuasa I., Saneshige Y., and Okada K. (1983a) Geographical cline of allele frequency of group-specific component (GC) in the Japanese populations: an analysis of data obtained by immunoelectrophoresis. The Japanese Journal of Human Genetics, vol. 28, pp. 255-261.

Yuasa I., Suenaga K., Ito K., Goto Y., and Okada K. (1983b) Distribution of GC polymorphism and geographical cline of GC allele frequency in the Japanese populations. Nippon Houigaku Zasshi, vol. 37, pp. 589 (in Japanese).

Yuasa I., Suenaga K., Gotoh Y., Ito K., and Yokoyama N. (1984) Gc types in western Japan: report of a new variant Gc 1C35. Human Heredity, vol. 34, pp. 174-177.

Yuasa I. (1987) Regional differences in the Japanese with special reference to the Japanese in Okinawa. Journal of the Anthropological Society of Nippon, vol. 95, p. 274.

Zeng Z. and Omoto K. (1987) Group-specific component (Gc) subtypes in two Chinese populations. The Japanese Journal of Human Genetics, vol. 32, pp. 83-89.

Corresponding author: Kazutoshi Ago (email: ago@med3.kufm.kagoshima-u.ac.jp)

Handling editor: Saitou Naruya 